Jurnal Pendidikan Dasar Indonesia dilisensikan di bawah

A Lisensi InternasionalCreative Commons Attribution-Non Commercial 4.0

\title{
Desain Pembelajaran Qur'an Hadist Model Jerold E. Kemp Berbasis Multimedia Di Madrasah Tsanawiyah
}

\author{
Asykur ${ }^{1)}$, Husniyatus Salamah Zainiyati ${ }^{2)}$, Siti Munawaroh ${ }^{3)}$ \\ ${ }^{1)}$ Pascasarjana UIN Sunan Ampel, Surabaya, Indonesia \\ E-mail: asykurmz85@gmail.com \\ 2) Pascasarjana UIN Sunan Ampel, Surabaya, Indonesia \\ E-mail: husniyatussalamah@uinsby.ac.id \\ 3) Pascasarjana UIN Sunan Ampel, Surabaya, Indonesia \\ E-mail: ceteem59@gmail.com
}

\begin{abstract}
Abstrak. Penelitian ini bertujuan untuk mengetahui pengaruh penerapan desain pembelajaran model Jelord E.Kemp berbasis Multimedia mata pelajaran al-Qur'an hadist dalam meningkatkan minat belajar siswa di MTs. Miftahul Ulum Timbuan. Guru mata pelajaran Al-Qur'an hadits dan siswa kelas VII di jadikan subyek dalam penelitian ini, sedangkan obyek dalam penelitian ini adalah penerapan pembelajaran model Jelord E.Kemp berbasis Mutimedia dalam meningkatkan minat belajar siswa kelas VII mata pelajaran Al-Qur'an hadits. Proses pembelajaran yang masih menggunakan metode konvensional di MTs. Miftahul Ulum Timbuan Kecamatan sarirejo Kabupaten Lamongan menyebabkan rendahnya minat belajar siswa sehingga berakibat pada hasil belajar siswa rendah di bawah batas KKM ( $\geq 70)$. Metode dalam penelitian ini dilakukan menggunakan Penelitian Tindak Kelas (PTK) dengan penerapan pembelajaran menggunakan model Jelord E.Kemp berbasis Multimedia dapat meningkatkan minat belajar siswa kelas VII MTs Miftahul Ulum sehingga hasil belajar yang di peroleh siswa sudah banyak yang mencapai KKM ( $\geq 70)$. Model Jelord E.Kemp berbasis Multimedia terlaksana dengan baik, Hasil penelitian menunjukkan peningkatan di setiap siklusnya. dapat dilihat dari data sebelum siklus 63,50\%, meningkat menjadi 70,00\% pada siklus I dan meningkat menjadi 82,00\% pada siklus II.
\end{abstract}

Kata kunci: Desain Pembelajaran, Model Jelord E.Kemp. Multimedia.

\begin{abstract}
This study aims to determine the effect of implementing the Jelord E. Kemp learning design model based on multimedia in the subject of al-Qur'an hadith in increasing student interest in learning at MTs. Miftahul Ulum Timbuan. The teacher of the hadith Al-Qur'an subject and the seventh grade students were the subjects in this study, while the object in this study was the application of the Mutimedia-based Jelord E. Kemp learning model in increasing the interest in learning of seventh grade students in the Al-Qur'an hadith subject. The learning process still uses conventional methods in MTs. Miftahul Ulum Timbuan, Sarirejo District, Lamongan Regency causes low student interest in learning, resulting in low student learning outcomes below the KKM limit $(\geq 70)$. The method in this study was carried out using Classroom Action Research (CAR) with the application of learning using the Jelord E. Kemp model based on Multimedia, which can increase student interest in class VII MTs Miftahul Ulum so that the learning outcomes obtained by many students have reached KKM ( $\geq 70)$. Multimedia-based Jelord E.Kemp Model was implemented well. The results showed an increase in each cycle. It can be seen from the data before cycle $63.50 \%$, increasing to $70.00 \%$ in cycle I and increasing to $82.00 \%$ in cycle II. Abstract. This study aims to determine the effect of implementing the Jelord E. Kemp learning design model based on multimedia in the subject of al-Qur'an hadith in increasing student interest in learning at MTs. Miftahul Ulum Timbuan. The teacher of the hadith Al-Qur'an subject and the seventh grade students were the subjects in this study, while the object in this study was the application of the Mutimedia-based Jelord E. Kemp learning model in increasing the interest in learning of seventh grade students in the Al-Qur'an hadith subject. . The learning process still uses conventional methods in MTs. Miftahul Ulum Timbuan, Sarirejo District, Lamongan Regency causes low student interest in learning, resulting in low student learning outcomes below the KKM limit $(\geq 70)$. The method in this study was carried out using Classroom Action Research $(C A R)$ with the application of learning using the Jelord E. Kemp model based on Multimedia, which can increase student interest in class VII MTs Miftahul Ulum so that the learning outcomes obtained by many students have reached KKM ( $\geq 70)$. Multimedia-based Jelord E.Kemp Model was implemented well. The results showed an increase in each cycle. It can be seen from the data before cycle $63.50 \%$, increasing to $70.00 \%$ in cycle I and increasing to $82.00 \%$ in cycle II.
\end{abstract}

Keywords: Learning Design, Jelord E.Kemp Model. Multimedia. 


\section{PENDAHULUAN}

Perkembangan Ilmu pengetahuan dan teknologi yang sangat pesat di berbagai bidang kehidupan tak luput menuntut adanya usaha yang ekstra keras dalam menemukan teknologi yang cocok untuk memperbaiki proses pembelajaran peserta didik dalam memfasilitasi belajarnya. Pendidik menjadi penanggung jawab utama dalam perbaikan proses belajar dan sebagai fasilitator dalam belajar yang di tuntut untuk mempunyai kemampuan yang lebih, sehingga tujuan tujuan pembelajaran bisa tercapai dengan sebaik-baiknya. Pembelajaran adalah suatu upaya yang terencana, bertujuan dan terkendali supaya orang lain belajar atau terjadinya transformasi yang relative menetap pada diri orang lain [1]

Pembelajaran merupakan separangkat tindakan yg dibuat guna mendukung proses belajar siswa, dengan memperhitungkan insiden-insiden yg berperan terhadap rangkaian kejadian-kejadian intern yg berlangsung dialami siswa [2].

Pendidik secara individu atau kelompok yang memiliki kemampuan dan kompetensi dapat merancang dan mengembangkan sumber belajar. Pembelajaran tidak harus di lakukan oleh seorang teknologi pendidikan atau suatu tiem ahli dalam bidang tertentu. Karena belajar adalah jalan atau metode alami yang menyebabkan perubahan apa yang sudah di ketahuinya dan bisa di lakukannya, dan bagaimana berprilaku. Akan tetapi salah satu fungsi dari suatu system pendidikan adalah untuk memfasilitasi pencapaian tujuan dari pembelajaran [3]

Peran seorang guru dalam kegiatan pembelajaran sangatlah penting. Tugas profesi guru meliputi mendidik, mengajar dan melatih. Mendidik dengan meneruskan dan mengambangkan nilai-nilai kehidupan. Mengajar dengan meneruskan dan mengembangkan ilmu pengetahuan dan teknologi. Sedangkan melatih dengan mengambangkan keterampilan peserta didik [4].

Dalam mewujudkan pembelajaran yang efektif, efisien dengan hasil yang maksimal perlu adanya staf pengajar sebagai individu yang terlibat langsung di dalam proses pembelajaran. Dalam hal ini staf pengajar di tuntut untuk meciptakan suasana pembelajaran yang efektif dan nyaman dengan membiasakan siswa selalu aktif dan komperatif saat proses belajar mengajar berlangsung sehingga target mutu pendidikan bisa tercapai.

Pendidik harus memperhatikan model-model pembelajaran yang sesuai dengan keadaan dan karakteristik gaya belajar siswa di saat melaksanakan proses pembelajaran, agar pembelajaran bisa berjalan secara sistematis dalam mencapai tujuan pembelajaran. Salah satu lembaga pendidikan SMP Negeri 3 sinjai timur yang telah mengunakan model pembelajaran Jerold E. Kemp dalam proses pembelajaran pendidikan agama islam dengan memberikan bimbingan kepada peserta didik untuk meningkatkan motivasi belajar [5]

Sedangkan media pembelajaran berperan sangat krusial dalam proses pembelajaran, banyak sekali macam penyajian pada media pembelajaran, antara lain berupa grafik, slide, foto, dan pembelajaran menggunakan memakai teknologi computer. Media pembelajaran yg memakai media computer sangat berperan pada menyalurkan, menyimpan dan memproses informasi, hal ini akan menjadikan proser pembelajaran sebagai komunikatif, efektif dan efisien [6]. Manfaat berdasarkan penggunaan media itu dibutuhkan bisa menarik perhatian anak didik dan memudahkan anak didik dalam memahami materi [7]. Pembelajaran jika didesain sesuai cara belajar manusia maka akan memberikan hasil yang lebih baik [8]

Multimedia interaktif adalah suatu multimedia yang dilengkapi dengan alat pengontrol yang dapat dioperasikan oleh pengguna, sehingga pengguna dapat Pengimplemantasian Media Pembelajaran Berbasis Multimedia Interaktif

Pembelajaran yg berorientasi dalam anak didik bisa dilakukan membentuk sistem pembelajaran yg memungkinkan anak didik mempunyai kemampuan untuk belajar yang lebih menarik, interaktif dan bervariasi. Siswa harus sanggup mempunyai kompetensi yg bermanfaat bagi masa depannya. Seiring menggunakan perkembangan teknologi berikut infrastruktur penunjangnya, upaya peningkatan kualitas pembelajaran bisa dilakukan melalui pemanfaatan teknologi tadi pada suatu sistem yg dikenal menggunakan online learning [9]. Belajar merupakan suatu proses yg berlangsung pada pada diri seorang yg mengubah tingkah lakunya, baik tingkah dalam berpikir, bersikap, dan berbuat [10]. Proses pembelajaran akan menghasilkan suatu tujuan yang akan di capainya, hal ini bisa tercapai bila mana di desain dengan berbagai model pembelajaran sesuai dengan keadaan dari peserta didiknya.

Model pembelajaran disusun berdasarkan berbagai prinsip atau teori pengetahuan. Para ahli dalam menyusun model pembelajaran berdasarkan prinsip pembelajaran, teori psikologis, sosiologis, analisis sistem dan teori lain yang tepat.

Jerold E. Kemp berasal dari California State university di sanjose Kemp yang paling awal mengembangkan model desain intruksional bagi pendidikan. Model yang di kembangkan Kemp dengan memberikan bimbingan kepada para siswanya untuk berfikir tentang tujuan pembelajaran dan masalah umum[11]. Model pembelajaran Jerold E.Kemp membentuk lingkaran atau cycle dalam sistem pembelajaran menunjukkan adanya proses yang kontinyu. Model ini termasuk dalam taksonomi model yang berorientasi pada pembelajaran individual dan klasikal [12].

Salah satu mata pelajaran Pendidikan agama islam yang diajarkan di madrasah tsanawiyah adalah mata pelajaran AlQur'an hadits, yaitu suatu bidang studi Islam yang banyak membahas tentang memahami isi kandungan Qur'an dan hadist. Dengan mata pelajaran ini diharapkan siswa dapat memahami dan mencintai Al-Qur'an dan hadits sebagai pedomana hidup mereka yang harus dipegang teguh dimanapun dan kapanpun mereka berada.

Dalam hal ini sebagaimana observasi pada pembelajaran di madarasah tsanawiyah Miftahul ulum sarirejo lamongan di masa pandemi Covid-19 ini yang dilaksanakan secara online dan offline, yang mana agar peserta didik berminat dan aktif dalam proses pembelajaran guru perlu mendorong dan mengembangkan segenap kemampuan dan kemauannya. Guru sudah berusaha supaya peserta didik berminat dan aktif dalam proses pembelajaran terutama pada mata pelajaran Qur'an hadist akan tetapi kenyataannya dalam proses pembelajaran masih terdapat siswa yang kurang berminat untuk mengikuti 
pelajaran kususnya pada kelas VII, dengan dapat dilihat dari adanya prilaku dari peserta didik sebagai berikut :

a. Ketika guru menerangkan pelajaran, terdapat siswa yang izin keluar masuk kelas.

b. Pada saat proses pembelajaran, terdapat siswa yang tidak memperhatikan dan berbicara dengan temannya.

c. Sebagian siswa ada yang tidak mengerjakan tugas.

Menurut [13] Mengukur keberhasilan dan prestasi yang di capai siswa sangatlah penting, karena akan menjadi bukti apakah proses pembelajaran tersebut dinyatakan telah berhasil dengan. Keberhasilan dalam proses pembelajaran bisa dicapai diperlukan beberapa aspek pendukungnya diantaranya : adanya tujuan yang jelas yang akan dicapai, adanya materi pembelajaran yang akan dikembangkan, adanya pelaksanaan kegiatan pembelajaran secara kontinyu serta adanya pelaksanaan evaluasi dalam pembelajaran.

Berdasarkan pengamatan rendahnya minat belajar siswa dalam proses pembelajaran pada mata pelajaran Al-Qur'an Hadist akan berpengaruh terhadap hasil belajar siswa yang cenderung menurun. Maka perlu berbagai cara untuk menyelesaikannya, salah satunya adalah melalui model pembelajaran Jerold E. Kemp dengan tujuan agar minat belajar siswa meningkat terutama di kelas VII di MTs Miftahul ulum timbuan tambakmenjangan sarirejo lamongan. Penulis mencoba melakukan penelitian dengan penerapan desain pembelajaran model Jerold E. Kemp pada mata pelajaran AlQur'an hadist dalam meningkatkan minat belajar siswa kelas VII di Madrasah tsanawiyah Miftahul Ulum timbuan kecamatan sarirejo Kabupaten Lamongan.

\section{METODE}

Penelitian ini dilakukan dengan menggunakan Penelitian Tindak Kelas (PTK). Penelitian tindak kelas adalah suatu kegiatan pencermatan terhadap belajar siswa yang berupa sebuah tindakan, yang sengaja ditimbulkan dan terjadi secara bersama-sama dalam sebuah kelas. Guru memberikan suatu tindakan atau arahan untuk dilakukan siswa [14].

Penelitian tindak kelas atau yang lebih dikenal dengan Classroom action research, dengan prinsipnya dilakukan untuk mengatasi permasalahn yang terjadi di dalam kelas. Dalam penelitian tindak kelas terdapat dua aktifitas yang dilakukan secara simultan yaitu (Action) aktifitas tindakan dan (research) aktivitas penelitian. Aktivitas tersebut dapat jalankan oleh individu maupun orang banyak dengan bekerjasama secara kolaboratif [15].

Penelitian berkait erat dengan persoalan sehari-hari yang dihadapi guru selama proses pembelajaran, penelitian tindak kelas merupakan suatu bentuk penelitian yang bersifat reflektif dengan melakukan tindakan yang sudah ditentukan [16].

Sampel penelitain tindak kelas ini di laksanakan di MTs Miftahul ulum Timbuan Kecamatan Sarirejo Kabupaten Lamongan, dengan waktu selama 2 bulan yakni terhitung mulai November-desember 2020. Yang menjadi subyek penelitian adalah guru mata pelajaran Qur'an hadist dan siswa kelas VII di MTs Miftahul ulum Timbuan Kecamatan sarirejo pada proses pembelajaran berbasis multimedia yang menerapkan model pembelajaran Jelord E.Kemp yaitu suatu model yang mengutamakan sebuah alur yang akan dijadikan pedoman untuk menyusun perencanaan program. Alur merupakan rangkaian yang sistematis dalam menghubungkan tujuan hingga tahap evaluasi. Guna meningkatkan minat belajar siswa kelas VII mata pelajaran Qur'an hadist di MTs Miftahul ulum Timbuan Kecamatan Sarirejo.

Penelitian ini menggunakan tiga siklus pembelajaran. PraSiklus dengan satu kali pertemuan, Siklus I dengan satu kali pertemuan dan Siklus II juga satu kali pertemuan. Dalam hal ini diuraikan sebagai berikut :

1. Pra Siklus yaitu melakukan Observasi dulu sebelum penerapan pembelajaran model Jerold E.Kemp berbasis multimedia yang mana guru masih mengunakan metode lawas kadang-kadang diselingi tanya jawab dan diskusi.

2. Siklus I yaitu awal impelementasi pembelajaran model model Jerold E.Kemp berbasis multimedia yang dibarengi dengan menganalisis kelemahan dan dilakukan evalusai pada siklus berikutnya.

3. Siklus II yaitu hasil akhir dari penerapan pembelajaran model Jerold E.Kemp berbasis multimedia, analisis data ditentukan dengan menggunakan presentasi persiklus yang digambarkan melalui grafik [17].

Penelitian tindak kelas ini menggunakan model Kemmis dan Taggart yang terdiri dari beberapa tahapan sebagai berikut :

1. Perencanaan

a. Tahap awal dalam pencanaan mempelajari kurikulum dengan memahami Kompetensi dasar dan buku ajar, untuk mempersiapkan bahan ajar dan membuat Rencana Pelaksanaan Pembelajaran (RPP) silabus, instrumen tes, instrumen observasi guru dan siswa, yang akan dipakai sebagai instrument pengumpulan data pada saat tindakan.

b. Peneliti menyusun petunjuk teknis pelaksanaan kegiatan desain pembelajaran dengan model Jerold E. Kemp, penelitian tindakan kelas dimulai pada pertemuan pertama.

c. Menerapkan beberapa variasi selama proses pembelajaran berlangsung, kususnya pada saat desain pembelajaran model Jerold E. Kemp dilaksanakan.

d. Menyusun rigkasan dari materi yang akan diajarkan untuk setiap pokok bahasan.

e. Mempersiapkan soal-soal yang yang akan di ujikan.

2. Tindakan

a. Peneliti menyerahkan bahan ajar yang berkenaan dengan materi yang akan diajarkan.

b. Peneliti menerangkan skema desain pembelajaran model Jerold E.Kem beserta langkah-langkah penerapannya.

c. Menyampaikan materi yang akan di ajarkan dan sebelum menjelaskan materi, perlu memberikan apersepsi guna ingin mengetahui sejauh mana pemahaman siswa terhadap materi.

d. Mengetahui karakteristik siswa guna menentukan indikator pencapaian hasil belajar.

e. Memilih sumber/alat pembelajarann untuk menentukan kegiatan pembelajaran.

f. Menentukan tes hasil belajar.

g. Mengevaluasi hasil tes ulangan dan menilai perkembangan siswa selama pembelajaran. 
h. Selanjutnya menyerahkan post test guna mengetahui tingkat keberhasilan pada setiap kegiatan pembelajaran yang telah dilaksanakannya.

3. Pengamatan / Observasi

Dalam tahap ini merupakan tahapan peneliti mulai mendokumentasikan proses pembelajaran, kondisi dan aspekaspek lain yang muncul dan tumbuh selama pelaksanaan tindakan. Hasil dari observasi akan dijadikan sebagai dasar untuk melakukan refleksi dalam membuat konsep tindakan selanjutnya. Disamping itu juga mengamati keadaan proses pembelajaran yang berlangsung serta apa yang terjadi akan dideskripsikan. Adapun aspek utama yang diniali adalah suatu yang berkerkenaan dengan perkembangan keaktifan siswa dalam peroses pembelajaran.

\section{Refleksi}

Tahapan ini peneliti menerangkan dan mengevaluasi, untuk mengetahui apakah yang di rencanakan dengan tindakan yang dilaksanakan sudah sesuai dega hasil analisis terhadap data, proses dan apakah sudah dilaksanakan dengan baik, akan tetapi bila terjadi kekurangan yang menjadikan hasil tidak bisa maksimal, maka butuh pengkajian ulang rencana untuk memperbaiki hasil yang maksimal.

Hasil dari observasi dan fekleksi akan dijadikan dasar untuk merencanakan langkah pada siklus selanjutnya, sehingga langkah disetiap siklus akan berbeda sesuai dengan kekurangan yang ada pada siklus sebelumnya. Dari perbedaan tersebut baik berupa variasi bahan materi multimedia mupun penggunaan alat bantu dan lain-lain.

Pada penelitian tindakan ini menggunakan data kuantitatif dan kualitatif. Analisis data kuantitatif dipergunakan untuk mengolah data setiap siklus berkaitan dengan prosentasi kenaikan nilai hasil belajar. Analisis data kualitatif dipergunakan untuk menganalisis data dari hasil catatan di lapangan dan catatan dokumentasi ketika melakukan penelitian.

\section{HASIL DAN PEMBAHASAN}

Ini Sebelum penerapan model pembelajaran Jerold E. Kemp berbasis multimedia dalam meningkatkan minat belajar siswa kelas VII MTs. MIftahul Ulum Timbuan Kecamatan Sarirejo Kabupaten Lamongan, dilaksanakan Observasi data terlebih dahulu. Peneliti telah melakukan observasi dengan hasil dapat dilihat pada table berikut:

\section{Tabel 1}

Observasi sebelum pembelajaran model Jerold E. Kemp Hari, Tanggal : Kamis, 05 November 2020.

Materi : Menggapai ridha allah swt dengan sikap dermawan dan menghindari Kikir.

$$
\text { Kelas : VII }
$$

\begin{tabular}{llc}
\hline No & \multicolumn{1}{c}{$\begin{array}{c}\text { Langkah Guru Prose } \\
\text { Pembelajaran }\end{array}$} & \multicolumn{2}{c}{$\begin{array}{c}\text { Hasil } \\
\text { pengamatan } \\
\text { Ya }\end{array}$} & \multicolumn{1}{c}{ Tidak } \\
\hline 1 & $\begin{array}{l}\text { Guru memilih materi dan tujuan } \\
\text { pembelajaran }\end{array}$ & $\sqrt{ }$ \\
2 & $\begin{array}{l}\text { Guru menganalisis } \\
\text { karakteristik siswa } \\
\text { Guru memilih tujuan pembelajaran } \\
\text { khusus }\end{array}$ & $\sqrt{ }$ \\
3 & & $\sqrt{ }$
\end{tabular}

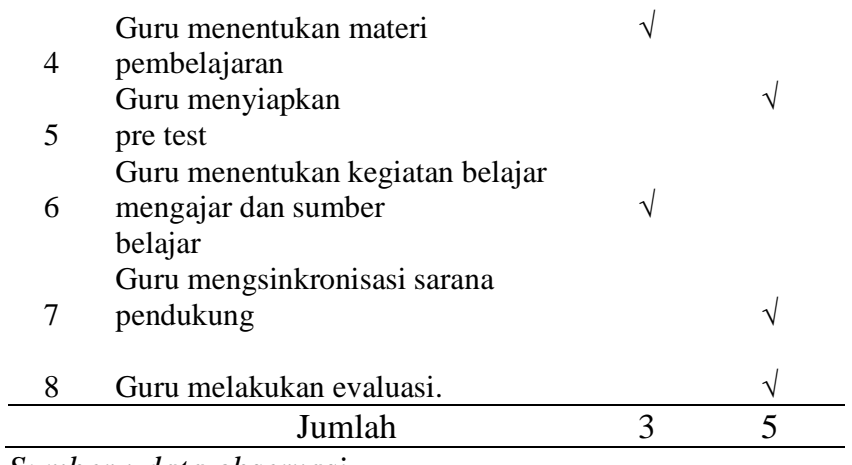

Hasil dari observasi diawal, bahwa dapat diketahui pada saat guru melaksanakan pembelajaran materi Menggapai ridha allah swt dengan sikap dermawan dan menghindari kikir belum menggunakan Model Pembelajaran Jerold E. Kemp.

Begitu juga masih rendahnya perhatian siswa kepada guru pada saat proses pembelajaran sebagaimana terlihat pada tabel observasi sebelum model pembelajaran Jerold E. Kemp diterapkan.

Tabel 2

Data Minat Belajar Siswa Kelas VII Sebelum (Pra Siklus)

Penerapan Model

Pembelajaran Jerold E. Kemp

\begin{tabular}{|c|c|c|c|c|c|c|}
\hline \multirow[b]{2}{*}{ No } & \multirow{2}{*}{$\begin{array}{l}\text { Item Observasi } \\
\text { terhadap siswa }\end{array}$} & \multicolumn{4}{|c|}{ Pilihan Jawaban } & \multirow{2}{*}{$\begin{array}{l}\text { Total } \\
\text { Frek }\end{array}$} \\
\hline & & $\mathbf{A}$ & B & $\mathbf{C}$ & D & \\
\hline 1 & $\begin{array}{l}\text { Siswa hadir } \\
\text { lebih awal }\end{array}$ & 4 & 5 & 11 & 0 & 20 \\
\hline 2 & $\begin{array}{l}\text { Siswa duduk } \\
\text { dengan tenang }\end{array}$ & 3 & 5 & 12 & 0 & 20 \\
\hline 3 & $\begin{array}{l}\text { Siswa } \\
\text { memperhatikan } \\
\text { guru }\end{array}$ & 4 & 3 & 15 & 0 & 20 \\
\hline 4 & $\begin{array}{l}\text { Siswa serius } \\
\text { dan fokus }\end{array}$ & 2 & 7 & 11 & 0 & 20 \\
\hline 5 & $\begin{array}{l}\text { Siswa aktif dan } \\
\text { antusias }\end{array}$ & 3 & 5 & 12 & & 20 \\
\hline 6 & $\begin{array}{l}\text { Siswa } \\
\text { mengerjakan } \\
\text { tugas }\end{array}$ & 4 & 4 & 12 & 0 & 20 \\
\hline 7 & $\begin{array}{l}\text { Siswa } \\
\text { mengerjakan } \\
\text { PR }\end{array}$ & 3 & 3 & 14 & 0 & 20 \\
\hline 8 & $\begin{array}{l}\text { Nilai siswa } \\
\text { meningkat }\end{array}$ & 4 & 4 & 12 & 0 & 20 \\
\hline 9 & $\begin{array}{l}\text { Siswa tidak } \\
\text { keluar masuk }\end{array}$ & 2 & 3 & 15 & 0 & 20 \\
\hline 10 & $\begin{array}{l}\text { Siswa tidak } \\
\text { pernah cabut }\end{array}$ & 0 & 7 & 13 & 0 & 20 \\
\hline & Jumlah & 29 & 46 & 127 & 0 & 200 \\
\hline & Presentasi & 14,5 & 23 & 63,5 & 14,5 & 100 \\
\hline
\end{tabular}

Sebelum menerapkan pembelajaran Model Jerold E.Kemp dapat diketahui bahwa minat belajar siswa masih rendah dengan presentasi $63,5 \%$, begitu juga ketuntasan hasil belajar siswa masih rendah dengan presentasi $36,00 \%$. Dengan hasil tersebut masih dinyatakan belum baik, karena masih terdapat 
banyak siswa yang belum memenuhi KKM. Setelah dilaksanakannya penerapan pembelajaran model Jerold E.Kemp pada Materi Menggapai ridha allah swt dengan sikap dermawan dan menghindari Kikir dalam Siklus I minat belajar siswa meningkat menjadi $70,00 \%$ dengan data telah tercapainya 9 siswa dari 20 siswa batas KKM $(\geq 70)$ atau $45,00 \%$, adapun 11 siswa masih belum mencapai batas ketuntasan, sebagaimana data lengkap pada tabel 3 di bawah ini:

Tabel 3. Hasil Belajar Siswa Siklus 1

\begin{tabular}{lc}
\hline Pencapaian & Hasil siklus I \\
\hline Nilai tertinggi & 82 \\
Nilai terendah & 45 \\
Nilai rata-rata & $63,50 \%$ \\
Tuntas & 9 Siswa \\
Belum tuntas & 11 Siswa \\
Ketuntasan Belajar & $70 \%$ \\
\hline
\end{tabular}

Dengan hasil analisis tersebut dapat dinyatakan data pada siklus I yatu masih banyak siswa yang kurang memperhatikan dalam proses pembelajaran.yang mana dengan hal tersebut masih belum memenuhi harapan peneliti. Karena siswa yang mencapai KKM masih di bawah $75 \%$.

Hasil dari analisis data pada Siklus ke II terdapat peningkatan minat belajar siswa mencapai $80 \%$ dengan tercapainya hasil belajar siswa menjadi $82 \%$ siswa yang sudah mencapai batas KKM ( $\geq 70)$, sebagaimana pada tabel 4 di bawah ini.

Tabel 4. Hasil Belajar Siswa Siklus 2

\begin{tabular}{lc}
\hline Pencapaian & Hasil siklus 2 \\
\hline Nilai tertinggi & 90 \\
Nilai terendah & 63 \\
Nilai rata-rata & $76,5 \%$ \\
Tuntas & 17 Siswa \\
Belum tuntas & 3 Siswa \\
Ketuntasan Belajar & $82,00 \%$ \\
\hline
\end{tabular}

Dengan jumlah siswa yang sudah mencapai batas KKM ( $\geq 70$ ) sebanyak 17 siswa dan 3 siswa yang belum tuntas. Maka dari catatan peneliti pada siklus II siswa sudah berkonsentrasi dalam proses pembelajaran, dan kondisi siswa di dalam kelas lebih baik dibanding pada Siklus I.

Hasil dari ketuntasan belajar siswa mencapai 82,00\%, hampir semua siswa mendapat nilai baik yang sudah mencapai indikator keberhasilan karena sedah mencapai batas KKM ( $\geq 70$ ). Sehingga siklus dapat di akhiri. Maka peneliti menyimpulkan bahwa penerapan pembelajaran model Jerold E. Kemp dapat meningkatkan minat belajar siswa kelas VII mata pelajaran Qur'an hadist di MTs. Miftahul Ulum Timbuan Kecamatan Sarirejo Kabupaten Lamongan, sehingga hasil belajar meningkat menjadi baik.

Dalam pengembangan pembelajaran ada beberapa model desain pembelajaran yang mengacu pada pendekatan sistem, antara lain model yang dikembangkan Jerrold E. Kemp (1985), model Walter Dick dan Lou Carey (1985), model I Nyoman Sudana Degeng (1989), dan masih banyak lagi.

Model Kemp merupakan model yang membentuk siklus. Menurut Kemp, pengembangan desain sistem pembelajaran terdiri atas komponen-komponen yang dikembangkan sesuai dengan kebutuhan, tujuan, dan berbagai kendala yang timbul. Model Kemp ini tidak ditentukan dari komponen mana seharusnya guru memulai proses pengembangan. Mengembangkan sistem intruksional, menurut Kemp dari mana saja, dengan syarat urutan komponen tidak dirubah, dan setiap komponen itu memerlukan revisi untuk mencapai hasil yang maksimal. Oleh karenanya, Model Kemp ini merupakan model yang sangat luwes [18]

Dalam mengembangkan pembelajaran Al-Qur'an Hadist bisa menggunakan model-model yang ada, atau dengan memadukan atau suatu model sendiri. Penggunaan suatu model tidak bersifat panasea (serba cocok untuk segala kondisi pembelajaran). Pemilihan dan penerapan suatu model desain pembelajaran untuk mengembangkan pembelajaran Al-Qur'an Hadist harus disesuaikan dengan kebutuhan pembelajaran, kondisi pembelajaran dan hasil pembelajaran, yang diharapkan. Untuk menghasilkan suatu produk pembelajaran Al-Qur'an Hadist, dengan diikuti langkah-langkah pengembangannya secara konsisten sehingga dapat menghasilkan produk pembelajaran Al-Qur'an hadist yang berkualitas.

Langkah-langkah pengembangan desain pembelajaran mata pelajaran al-Qur'an hadits dengan menggunakan model Jerold E.Kemp menurut [19] terdiri dari delapan langkah, yakni :

a. Menentukan tujuan intruksional umum (TIU): yaitu tujuan umum yang ingin dicapai dalam mengajarkan masingmasing pokok bahasan.

b. Menganalisis karakteristik peserta didik. Analisis ini diperlukan antara lain untuk mengetahui apakah latar belakang pendidikan dan social budaya peserta didik memungkinkan untuk mengikuti program, serta langkahlangkah apa yang perlu diambil.

c. Menentukan tujuan instruksional khusus (TIK), operasional dan struktur (indikator). Dengan demikian peserta didik akan mengetahui apa yang harus dikerjakan, bagaimana mengerjakannya, dan apa ukurannya bahwa ia telah berhasil. Bagi guru, rumusan itu akan berguna dalam menyusun tes kemampuan atau keberhasilan dan pemilihan materi atau bahan ajar yang sesuai.

d. Menentukan materi atau bahan ajar sesuai dengan tujuan pembelajaran khusus (indikator) yang telah dirumuskan. Masalah yang seringkali dihadapi guru-guru adalah begitu banyaknya materi pelajaran yang harus diajarkan dengan waktu yang terbatas. Demikian juga, timbul kesulitan dalam mengorganisasikan materi atau bahan ajar yang akan disajikan kepada peserta didik. Dalam hal ini diperlukan ketepatan guru dalam memilih dan memilah sumber belajar, materi, media, dan prosedur pembelajaran yang akan digunakan.

e. Menggadakan tes awal (pre test/assessment). Hal ini diperlukan untuk mengetahui sejauh mana pengetahuan awal peserta didik dalam memenuhi prasyarat belajar yang dituntut untuk mengikuti program pembelajaran yang akan dilaksanakan. Dengan demikian, guru dapat memilih 
materi yang diperlukan tanpa harus menyajikan yang tidak perlu, sehingga siswa tidak menjadi bosan.

f. Menentukan strategi pembelajaran, media, dan sumber belajar. Kriteria umum untuk pemilihan strategi pembelajaran yang sesuai dengan tujuan intruksional khusus (indikator) tersebut, adalah efisiensi, keefektifan, ekonomis, praktis, melalui sebuah analisis alternatif.

g. Mengkoordinasi sarana penunjang yang meliputi biaya, fasilitas, peralatan, waktu dan tenaga.

h. Menggadakan evaluasi. Evaluasi ini sangat perlu untuk mengontrol dan mengkaji keberhasilan program secara keseluruhan, yaitu siswa, program pembelajaran, alat evaluasi (tes), dan metode atau strategi yang digunakan.

\section{KESIMPULAN}

Berdasarkan pemaparan dari analisis, peneliti dapat menyimpulkan hasil penelitian sebagai berikut :

1. Penerapan model pembelajaran Jerold E. Kemp berbasis multimedia pada siswa kelas VII mata pelajaran alQur'an Hadist di MTs. Miftahul Ulum Timbuan Kecamatan Sarirejo Kabupaten Lamongan sudah terlaksana dengan hasil yang baik, dapat dilihat dari peningkatan di setiap siklusnya, sebelum siklus $63,50 \%$, meningkat menjadi $70,00 \%$ pada siklus I dan meningkat menjadi $82,00 \%$ pada siklus II.

2. Penerapan model pembelajaran Jerold E. Kemp berbasis Multimedia memberikan hasil dapat meningkatkannya minat belajar siswa kelas VII mata pelajaran al-Qur'an Hadist di MTs. Miftahul Ulum Timbuan Kecamatan Sarirejo Kabupaten Lamongan, sehingga berpengaruh terhadap hasil belajar siswa menjadi baik dengan hasil akhir 17 siswa dapat mencapai batas KKM $(\geq 70)$ dengan presentasi ketuntasan belajar 82,00\% .

\section{UCAPAN TERIMA KASIH}

Kami ingin mengucapkan terima kasih kepada bapak kepala Madrasah beserta pendidik dan tenaga kependidikan Tsanawiyah Miftahul Ulum Timbuan Kecamatan sarirejo Kabupaten Lamongan yang telah memberikan izin serta dukungan sehingga penelitian ini bisa terlaksana dan dapat terselesaikan dengan baik.

\section{REFERENSI}

[1] Yusufhadi Miarso, "Menyemai Benih Teknologi Pendidikan,” Jakarta: Prenada Media Group, 2004, p. 545.

[2] Akhiruddin, Sujarwo, H. Atmowardoyo, and Nurhikmah, BELAJAR DAN PEMBELAJARAN. CV. CAHAYA BINTANG CEMERLANG, 2019.

[3] R. M. Gagne, W. W. Wager, K. C. Golas, J. M. Keller, and J. D. Russell, "Principles of instructional design, 5th edition," Perform. Improv., 2005, doi: 10.1002/pfi.4140440211.

[4] U. Usman, "Menjadi Guru Profesional," Bandung: PT. Remaja Rosdakarya, 2002, p. 19.

[5] R. RAHMATULLAH, "IMPLEMENTASI MODEL PEMBELAJARAN JEROLD E. KEMP DALAM MENINGKATAKAN MOTIVASI BELAJAR
PESERTA DIDIK PADA MATA PELAJARAN ...." repository.iaimsinjai.ac.id, 2018.

[6] M. Mustika, E. P. A. Sugara, and M. Pratiwi, "Pengembangan Media Pembelajaran Interaktif dengan Menggunakan Metode Multimedia Development Life Cycle," J. Online Inform., 2018, doi: 10.15575/join.v2i2.139.

[7] A. Purwanto, M. Hendri, and N. Susanti, "Studi Perbandingan Hasil Belajar Siswa Menggunakan Media PhET Simulations dengan Alat Peraga pada Pokok Bahsan Listrik Magnet di Kelas IX SMPN Kabupaten Tebo," J. EdulFisika, 2016.

[8] G. Gunawan, A. Harjono, and I. Imran, "PENGARUH MULTIMEDIA INTERAKTIF DAN GAYA BELAJAR TERHADAP PENGUASAAN KONSEP KALOR SISWA," J. Pendidik. Fis. Indones., 2016, doi: 10.15294/jpfi.v12i2.5018.

[9] A. Zakariyah and A. Hamid, "Kolaborasi Peran Orang Tua dan Guru dalam Pembelajaran Pendidikan Agama Islam Berbasis Online di Rumah," Intizar, 2020, doi: 10.19109/intizar.v26i1.5892.

[10] W. Gulo, Strategi Belajar Mengajar. Jakarta, 2002.

[11] Rusman, "Model-Model Pembelajaran, Mengembangkan profesionalisme Guru," Jakarta: Rajawali Pres, 2016, pp. 166-167.

[12] F. Fatmawarni and D. N. Chania, "PENGARUH MODEL PEMBELAJARAN JEROLD E. KEMP TERHADAP HASIL BELAJAR MANAJEMEN KEUANGAN PADA PROGRAM STUDI PENDIDIKAN ...," LIABILITIES (JURNAL Pendidik. ..., 2020.

[13] Wekanis. A.S \&Hamadi. M, "Strategi Mengajar Dalam Pelaksanaan Kurikulum Berba sis Kompetensi," semarang: Sutra Benta Perkasa, 2005, p. 35

[14] S. Arikunto, "Penelitian Tindakan Kelas," Jakarta: Bumi Aksara, 2009.

[15] Suhendar T, "Penelitian Tindakan Kelas," Jakarta: Departemen Pendidikan Nasional, 2009.

[16] Mahmud and Tedi priatna, "Penelitian tindak kelas teori dan praktek," Bandung: Tsagrafika, 2008.

[17] FX Sudarsono, "Aplikasi Penelitian Tindakan Kelas," Jakarta: (Jakarta: Departemen Pendidikan Nasional, 2001, p. 26.

[18] Hamdani, Strategi Belajar Mengajar. Bandung: Pustaka Setia, 2011.

[19] Rusman, Model-Model Pembelajaran. Jakarta, 2013. 